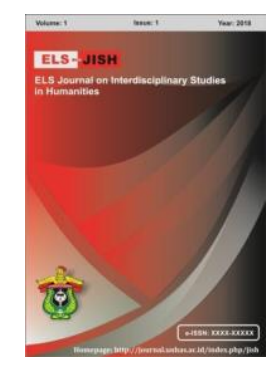

ELS-JISH

ELS Journal on Interdisciplinary Studies on Humanities

Volume 3 Issue 3, 2020

ISSN (print) : 2621-0843

ISSN (online) : 2621-0835

Homepage : http://journal.unhas.ac.id/index.php/jish

\title{
Mood and Modality Analyses in Investigating Ideology of News About Indonesia in BBC World Webnews
}

\author{
Diah Supatmiwati ${ }^{1}$, Martin L. Manda ${ }^{2}$, Noer Jihad Saleh ${ }^{3}$, Mustafa Makka ${ }^{4}$ \\ ${ }^{1}$ diah quth@yahoo.com
}

\begin{abstract}
The primary aim of this study is to investigate the influence of ideology on news. The goals are to determine the interpersonal characteristics of the text and to link them to the ideologies that they can realize. The clause's mood structure is the means by which the fundamental differences are realized at the lexicogrammatical level within the contextual register variable of Tenor. Specifically, participants in an interaction encode their perception (or at least their ostensible perception) of both their relationships with others and the social and situational sense in which the interaction takes place through choices of mood elements such as topic and finite. There is a close complementarily between mood and modality and it is for this reason that the two systems have been analyzed together. Finally, the findings relate to the overall meaningmaking and ideology-conveying resources of the text as a whole. The selected webnews consist in a set of texts. They were English articles with the general purpose to observe how Indonesian was portrayed in the BBC International Website or by the world.
\end{abstract}

Keywords: Mood, Modality, Ideology.

How to cite: Supatmiwati, D., et. al. (2020). Mood and Modality Analyses in Investigating Ideology of News About Indonesia in BBC World Webnews. ELS Journal on Interdisciplinary Studies in Humanities, 3(3), 408-414. DOI: https://doi.org/10.34050/elsiish.v3i3.11238

\section{Introduction}

The means by which the fundamental distinctions within the contextual register variable of Tenor are realized at the lexicogrammatical level is the clause of the mood structure. Especially, choices of mood elements namely Subject and Finite that people in interaction encode their understanding the other and situational context occur. In addition, Rahman (2018) stated understanding meaning will never relate without context. For example, And variations between information exchanges (statements or questions) or what Halliday calls 'goods and services' (orders or offers) are related to the variations between major and minor types of clauses in mood. Such typical associations are known as 'unmarked' while 'marked' are considered untypical associations. Instances of markedness in a clause are typically driven in some way-for specific purposes, such as politeness, the text creator has deviated from

1,2,3,4 Hasanuddin University, Indonesia. 
prototypical usage. As such, marked structures are usually worth taking care of in the analysis.

In addition to recognizing the interpersonal relationships between interactants, from the point of view of the present analysis, a significant feature of the Mood structure is that it can also be seen semantically as realizing what Halliday calls the clause' arguable nub ': statements about what is or is not the case or what must or must not be done. Significance gradations are realized between the polar opposites of is and is not, do and don't, realized through the Mood system, by choices of the different modality resources such as modal operators and Mood adjuncts.

For interactors, modality is an essential resource in which to communicate their attitudes and assessments about the subject matter of the text, themselves and each other. There is thus a close complementarily between Mood and Modality and it is for this reason that the two systems have been analyzed together here. In the next section the results of coding the text for Mood and Modality to be presented in. Subsequent sections then discuss the findings of this analysis.

The aim is to (a) explain the interpersonal characteristics of the text and (b) link them to the ideologies they can understand. The mood and modality structures of all rankings and embedded clauses are discussed in this section. They are coded in accordance with the key provided in the appendix. Notice that, as is also the case with other systems, in the Mood or Modality systems, certain words, groups or phrases do not play a role and are therefore not coded here.

It is perhaps worth pointing out that the features to be discussed here are those which the comprehensive analysis of Mood has shown to be particularly prevalent or significant in this text. Thus it is the analysis which precedes and determines the identification of noteworthy features rather than the other way round. This is an important principle for the present study because it helps increase its objectivity and explicability, which in turn helps to counter criticisms frequently made that CDA research is guided(to put it mildly) by the researcher 'presuppositions about what is worth investigating(e.g Stubbs, 1997; Widdowson 2 004).

Two points should however, be borne in mind. Firstly, the approach used here cannot entirely eliminate the guidance given by the invisible hand of presupposition For example, the very decision to proceed in the way I have described stems from the fact that I have assumed (strategically it might be said) very generally that all aspects of a text may, potentially, convey, construe or afford ideological meaning. However I take it that the philosophical arguments about the possibility of absolutely disinterested knowledge about human affairs have by and large been settled with the conclusion that such knowledge (including knowledge of this matter itself) is not possible (Nagel 1986). Nevertheless, as an ideal to be aspired to, I believe the very notion of such a possibility has a useful role in motivating attempts to produce high quality research. The second point is that caution must be exercised in 
assuming that significance can be ascribed automatically to frequency of occurrence.

Finally, the primary purpose of this research is to examine the effect on news of ideology. The goal is to (1) define the interpersonal characteristics of the text and (2) link these to the philosophies that can be realized by the clause's MOOD structure. It is the means by which the fundamental distinctions are realized at the lexicogrammatical level within the contextual register component of Tenor.

\section{Method}

The data collected relies on news articles as discourse text to be analyzed. This study is focused primarily on qualitative analysis. This section is divided into three parts : the first part is data collection, the selected news website is defined, the second part explains the coding of the selection criteria for the selected papers, and the third part describes the methods used in the study.

The method of collecting relevant information and data in the sense of this analysis included library research. The primary research data consists of news articles / texts taken from BBC International and the articles / texts are from January 2017 to December 2017. News stories that are written in English on the BBC International website. Listed texts differ in length and number of texts, respectively.

\section{Findings and Discussion}

Although the analysis here pays attention to certain characteristic trends that are frequently occurring (such as full declaratives), it also aims to be alert to the significance of unique or uncommon characteristics. Table 1 below outlines the coding results for Mood. Table 1 Mood analysis of the rating clauses.

Table 1. Mood Analysis of Ranking Clauses

$$
\text { MOOD (rangking clauses only) }
$$

\begin{tabular}{lcc}
\hline Mood class & Text En04 & Text Ina04 \\
Full declarative & 240 & 260 \\
Elliptical declarative & 0 & 1 \\
Full polar interogative & 0 & 3 \\
Elliptical polar interogative & 0 & 0 \\
Full WH-interogative & 1 & 2 \\
Elliptical WH-interogative & 0 & 0 \\
Imperative & 0 & 0 \\
Minor & 0 & 0 \\
Abondoned/incomplete & 0 & 0 \\
Total rangking clauses & & \\
\hline
\end{tabular}

As Table 1 shows, either text En04 or Ina04 A very small number of choices from the MOOD system were consistently selected. The complete declarative was the most frequently used clause form. This reliance on 
complete declaratives is characteristic of the structured news texts' non-dialogic style. The asset being exchanged is data in such texts, from either print to digital news, and the relationship between writer / journalist and viewer is one in which there is no chance of viewer input.

Such MOOD choices, in conjunction with other aspects of the text, lead, on the one hand, to the creation of an authoritative and distant subject position for the text writer as an information provider and, on the other hand, a passive function for the audience as an information recipient. The interpretation of information by the viewer should not be strictly passive or uncritical, as study has also been seen in media interpretation and viewer studies. (Ang 1996; Moores 1993). However, as Nicholas Garnham (2000) Based on his analysis of the Hegelian origins of product fetishism, he argued that it is entirely possible for an engaged audience to engage actively in its own supremacy.

The main point is that on the semiotic level the grammatical choices made by the text journalist preferentially afford such roles for speakers and audience. Also, in the absence of clear factors that appear to the contrary, it is fair to conclude that speakers are more involved than listeners and that the former is authoritative in relation to the latter because of the unidirectional, monological nature of the communication.

In this case, the conversation itself is not an actual one, carried out by a group of co-present participants at a specific space-time conjunction, but it is possible that the interpersonal relationships between the participants and those between the participants and the audience will interact in very complex ways. As the table 1 shows text En04 uses only two Mood type, the full declarative which is common in writen mode where feedback between writer and reader is not possible and The text contains only one Full WH-interogative clauses which is strongly expressive of role relationships.

"Why you are making our lives so difficult?"

These clause contribute dialogic mode in text En04 in general, as might otherwise be realized in more formal registers, there are no other MOOD elements to indicate that text is engaged in a dialogue. However, while text Ina04 is also written, it does select three Mood from outside the declarative Mood, with one Elliptical declarative, 2 Full WH-interogative and 3 Full polar interrogative.

1. Elliptical declarative

1) "Tidak. Alhamdullilah tiada yang kami rindukan (dari kehidupan lama), sekarang sangat berbeda, saya bahagia dengan kehidupan baru."

2. Full $\mathrm{WH}$-interogative

1) Seberapa panjang sih umur manusia?

2) "Mengapa kalian membuat hidup kami begitu susah?"

3. Full polar interrogative

1) apakah sebelumnya hidup mereka tidak punya tujuan? 
2) Apakah ada yang Anda rindukan dari kehidupan lama di hutan dan mendengar nyanyian burung?

3) apakah sama sekali tidak ada budaya Orang Rimba yang ingin Anda wariskan ke anak-anak? Mungkin bagaimana Orang Rimba menjaga kebersihan sungai dan melindungi hutan?

Surprisingly only one Mood type of Full WH-interogativein En04 has the realisation in text Ina04 (En04"Why you are making our lives so difficult?" Ina04"Mengapa kalian membuat hidup kami begitu susah?"), and the Full polar interogative found in Ina04 has the potential to create dialogue mode. The interogativeallows the text to seem interactive, in those mode the witer is in the position of as a questioner. each of these choices contributes significanly to the meaning being made in the texts.

The dominance of full declartive in both texts En04 and Ina04 indicate that the texts share a common focus on giving of Information. Hoewver the patern of modality in the texts provide evidence to support the claim that there is a difference between type of information being offered. Now it turn to a consideration of the MODALITY features of the text, the results of the Modality analysis presented in Table 2 below.

Table 2. Modality and Polarity

\begin{tabular}{lcc}
\hline & Modality and Polarity \\
\hline Type & Text En04 & Text Ina04 \\
Modalization & 23 & 21 \\
Modulation & 5 & 5 \\
Negation & 16 & 15 \\
Total rangking clause & & \\
\hline
\end{tabular}

From the summary presented in Table 2 it is evident that the text as a whole makes rather little use of Modality and Polarity resources. In particular, we may note that very little Modality and Polarity is expressed directly through the core Mood block constituent, the Finite itself. The table 2 above indicate the frequency with which modality and polarity are expressed throufh verbal constituents of the clause. As the result show text Ina04 has the lower use of modality than text En04, but the ratio of modalization to modality is approximately the same. The fact that very little MODALITY used in this text are the most noteworthy findings of this analysis. It is an example of the high degree of realism involved with the presentation of news that the news presenting and reporting workers do not use verbal modalization here. In the other hand, since the texts are essentially concerned with information exchange (specifically giving) rather than 'goods and services'. These findings demonstrate how this news text is constructed from a tightly restricted range of options from the systems of Mood and Modality and how it relates to the contextual variables of Genre and Register from which it was created..

Some further observations on Mood Adjunct usage in this text presented in the table 3 below. 
Table 3. Types of Adjuncts

\begin{tabular}{lcc}
\hline \multicolumn{3}{c}{ ADJUCNTS } \\
\hline Type of Adjucnts & Text En04 & Text Ina04 \\
Circumstantial & 87 & 98 \\
Mood & 26 & 34 \\
Comment & 0 & 0 \\
Polarity & 0 & 0 \\
Conjucntive & 71 & 67 \\
Continuity & 0 & 0 \\
Total Adjuncts & & \\
Total rangking clause & & \\
\hline
\end{tabular}

The results show in the table 3 that in both texts En04 and Ina04 the number of adjucts are slightly less than the number of ranking clauses. Thus a considerable porpotion of the meaning made in these two texts are made as non core, non arguable information. This can be intepreted as a strategy by which the writer autority is created and protected. In addition, a relatively high number of circumstantial adjuncts occur both in the tetxts En04 and Ina04 create porpotion of meaning.

\section{Conclusion}

It can be shown that only a comparatively narrow range of options have been selected from the overall Lexicogrammatic tools for interpersonal meaning-making at the level of the Clause by the study of the mood and modality trends deployed in both text En04 and text Ina04. These represent the influence of Tenor's Register Variable: the way in which the interpersonal nature of the context finds its expression in the text. It is the particular configuration of these options which define the nature of the texts. In this case, it is a highly Statements, in which, and somewhat contradictorily, in the form of Circumstantial Adjuncts, much of the meaning is placed beyond the arguable nub of the Mood block feature. The definitions of experience tend to be particulate: they organize segmental texts. They organize the text into wave-like knowledge peaks and troughs; and mood adjuncts indicate interpersonal meanings., that we may expect to find interpersonal meanings most powerfully realized. In the present study therefore, although within the clause at the lexicogrammatical level Interpersonal meanings mainly converge in the mood and modality systems their Impact is also felt in the experiential system of Transitivity Accordingly.

\section{References}

Eggins, S., (2004), Introduction to Systemic Functional Linguistics, A\&C Black.

Fairclough, N. (1995b). Media Discourse. London: Edward Arnold

Fairclough, N. \& Wodak, R. (1997). Critical Discourse Analysis. In T. A. Van Dijk (ed.), Discourse as social interaction (pp. 258-284). London: Sage.

Fairclough, N. (2000). The discourse of social exclusion. In M. Reisigl, and $R$. Wodak (eds), The Semiotics of Racism: Approaches in Critical Discourse Analysis (pp. 65-84). Vienna: Passagen Verlag. 
Fairclough, N., (2003), Analysing Discourse: Textual Analysis for Social Research, London: Routledge.

Halliday, M.A.K.,\& R. Hasan,, (1985/1989), Language, Context and Text:Aspects of Language in a Social-Semiotic Perspective, Oxford: Oxford University Press.

Halliday, M.A.K., \& C.M.I.M. Matthiessen, (2004), An Introduction to Functional Grammar, (third edition). London: Arnold.

Rahman, F. (2018). The Constraints of Foreign Learners in Reading English Literary Works: A Case Study at Hasanuddin University. Journal of Arts and Humanities. 7 (02), pp. 01-12.

Sudaryanto, (2015) Metode dan Aneka Teknik Analisa Bahasa: Pengantar Penelitian Wahana Kebudayaan Secara Linguistis Yogjakarta: Sanata Dharma University Press

Supatmiwati, Diah (2010). Characters of william shakespeare in translation on shakespeare in love subtitling: a systemic functional linguistic approach Unpublished dissertation. Denpasar: Udayana University

Van Dijk, T. A. (Ed.) (1985a). Discourse and Communication: New Approaches to the Analysis of Mass Media Discourse and Communication. Berlin: de Gruyter.

Van Dijk, T. A. (1985b). Structures of News in the Press. In T. A. van Dijk (ed.), Discourse and Communication: New Approaches to the Analysis of Mass Media Discourse and Communication (pp. 69-93). Berlin: de Gruyter.

Van Dijk, T. A. (1988). News as Discourse. New York: Erlbaum.

Van Dijk, T. A. (1988). Text and Context: Exploration in the Semantics and Pragmatics of Discourse. New York: Longman Group Ltd

Van Dijk, T. A. (1998). Ideology: a Multidisciplinary Study. London: Sage.

Wodak, R. (Ed.) (1989). Language, Power and Ideology. Amsterdam: John Benjamins. 